ISSN 0554-6397

UDK: 004.032 .26

Original scientific paper

Received: $18^{\text {th }}$ April 2020

\author{
Marinela Krstinić Nižić \\ University of Rijeka, Faculty of Tourism and Hospitality Management in Opatija \\ Primorska 42 c, 51410 Opatija, Croatia \\ E-mail: marikn@fthm.hr

\section{Ksenija Vodeb} \\ University of Primorska, Faculty of tourism studies - Turistica, Portorož, Slovenia \\ E-mail: ksenija.vodeb@fts.upr.si

\section{Zvonimira Šverko Grdić} \\ University of Rijeka, Faculty of Tourism and Hospitality Management in Opatija \\ Primorska 42 c, 51410 Opatija, Croatia
}

\title{
The Smart City Concept for Sustainable Development of a Tourist Destination
}

\begin{abstract}
Purpose - At a time of exceptionally fast technological advancement, smart cities have become necessary for the better management of existing resources in a tourist destination. The aim of this paper is to investigate if the smart city concept has been recognized in micro destinations in the Kvarner region for the purpose of sustainability and raising residents' quality of life.

Design/Methodology - The research has been conducted in the Kvarner tourist destination in December 2019. Citizens were asked their opinions within the scope of the following narrow tourist destinations - Lovran, Opatija and Rijeka. The questionnaire used closed-ended questions. This short research focuses on public perception regarding the smart city concept.

Findings - The results show that $67 \%$ of the people living in tourist destinations are not familiar with the smart city concept. Most, however, state that its implementation would improve the touristic development of the destinations. The development of smart destinations leaves plenty of room for each community undertaking that step to define the shape and functionality of its environment while respecting the community's historical, cultural-artistic and social heritage.

Originality of the research - There are many papers dealing with the topic of smart cities, but it is rare for authors to explore the transformation of traditional tourist destinations into contemporary sustainable communities. The obtained results can be used to inform policy making towards becoming more proactive, smart and sustainable.
\end{abstract}

Keywords: smart cities, sustainable tourist destinations, urban sustainability, local economy 


\section{Introduction}

At a time of exceptionally fast technological advancement, smart cities have become a necessity. A smart city involves the use of information-communication technologies in an urban touristic environment for the purpose of achieving better management of existing resources, planning the creation and development of new processes and services, as well as positioning citizens and visitors at the heart of the urban, economic and political dynamics of a city's development [1,2]. The development of smart destinations leaves plenty of room for each community undertaking that step to define the shape and functionality of its environment while respecting the community's historical, cultural-artistic and social heritage [3]. The transformation of any environment into a smart city is a long-term process. Its initial phase, strategic development planning, is an important prerequisite for a successful transformation [4]. The smart city concept entails an entire sustainable city in which the quality of human life and relationship towards its natural environment will be on a significantly higher level $[5,6]$. Citizens, with their creativity, knowledge and skills, along with a well-networked city infrastructure and user-oriented services, represented the main advantage of contemporary cities in the context of achieving economic growth and a higher quality of life. A smart city can be defined as an approach to urban development utilizing digital and communication technologies in order to better fulfil citizens' needs and improve the efficiency of city services. There is no singular definition of a smart city, but the general understanding in the media and everyday use is ,,a city that uses digital technologies to improve productivity and public welfare while reducing financial expenses and resource expenditure and at the same time publicly involving citizens in all of these aspects [7]. Cities and city infrastructure are very complex systems that have to efficiently respond to many needs on a daily basis [8]. This also includes tourist destinations where the number of visitors is continuously on the rise. Solutions for smart cities encompass various demands, limitations and challenges faced by tourist destinations. The aim of this paper is to investigate if the smart city concept has been recognized in micro destinations in the Kvarner region for the purpose of sustainability and raising quality of life. Well-known tourist destinations - Lovran, Opatija and Rijeka - have been selected as the sample, and citizens of these three destinations were randomly selected and polled. The goal was to verify to what extent the residents are aware of the smart city concept. The paper contains an introduction and two additional chapters. The first part provides the definition of a smart city and the literature overview. There is an overview of the aspects, characteristics and areas of activity pertaining to smart cities. The second part presents the research conducted based on a questionnaire. We have analysed the residents attitudes regarding the concept and their informedness on the implementation of the smart city concept in a tourist destination. Finally, the last part presents the discussion on smart cities and obstacles for its implementation. The conclusion is that there is great potential for smart cities and that it is a considerable way for changes to start taking place on the micro level. Parallel with economic and 
social development, implementing the smart city concept develops and improves the ecological system, which supports the principles of sustainable development in a tourist destination [9].

\section{Literature review}

By the year 2050, more than 6 billion people will live in urban areas [10]. Such a development requires smart solutions in order to ensure optimal economic activity, energy expenditure, environmental impact and a high quality of life in cities. The road to a smart, sustainable city is long and it requires long-term planning in order for a city to develop with its citizens $[11,12]$.

Growing cities worldwide face challenges in aligning competitive and sustainable urban development. A large part of the world's population resides in cities, making up $70 \%$ of the world's total $\mathrm{CO} 2$ emissions, and are the biggest consumers [13]. Many cities face environmental and climate challenges which significantly affect lives, as well as developmental challenges [14]. The need for smart urban solutions has never been greater. Urbanization leads to a great demand for sustainable solution, stable energy, fresh and potable water, efficient transportation and resource management $[15,16]$. Cities affect climate change, and they are in turn affected by those changes [17]. In order to solve these issues, cities have to be more energy efficient, focused on consumers, and guided by technology [18]. It is mostly based on using smart grids, better implementation of ICT, use of the Internet of Things, applying M2M communication, reducing pollution, implementing intelligent transportation systems, as well as increasing energy efficiency through smart measurement and implementation of innovative solutions in civil engineering [19,20]. Other terms used for smart cities include cyberville, digital city, electronic community, flexicity, information city, intelligent city, city based on knowledge, telecity, teletopia, omnipresent city, wired city etc. [21,22]. With the further rise of technology in recent years, there has been plenty of ideas about how to live smarter in cities and this topic has become the focus of world leaders and private industries. Millions of euro are being invested in research and development of pilot projects contributing to setting up truly smart cities [23, 24]. Rapid urbanization is taking place worldwide, which means that cities are becoming crowded and this can have negative consequences if the city does not carefully plan its development. According to research, every week a million people move from rural to urban areas, chasing economic opportunities offered in cities. Presently, nearly 4 billion people live in urban areas, making up more than half of the world's population [25]. It is forecasted that by the year 2050 migrations from rural to urban areas will peak, as shown by Graph 1. 


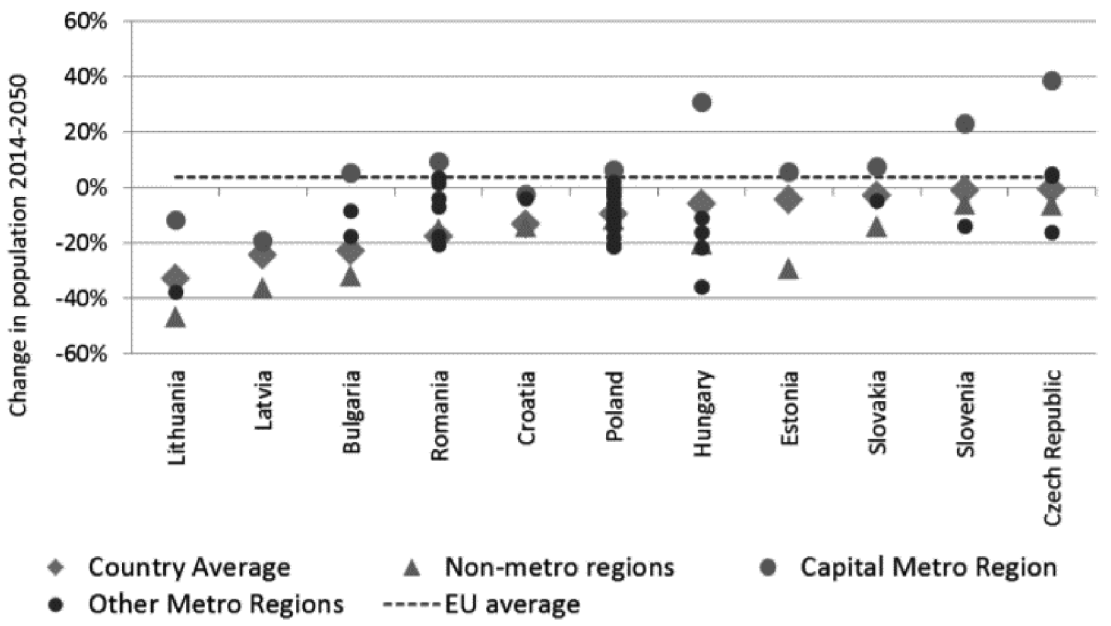

Figure 1 - Demographic projections (2014-2050) by metropolitan areas [26]

The projections for Central, Eastern and South-Eastern European cities show that capitals are expected to register relatively positive dynamics, while second-tier cities are expected to decrease in population. This scenario has multiple policy implications: second-tier cities can play a crucial role in retaining and attracting population by offering alternatives to congested (and therefore less productive than optimal) capitals for studying, working and doing business; urbanization economies (dependent on the size of the cities) will not strongly support the convergence of second-tier cities. Consequently, higher productivity and more innovation and knowledge sharing are required to support the economic catch-up of second-tier cities. It is therefore necessary to develop smart and sustainable solutions for a higher quality of life in urban destination in accordance with urbanization and city development.

\section{Smart city characteristics}

The smart city concept was developed as a natural response to urbanization, the economic significance of cities and an increase need for sustainable life [27, 28]. The most important thing in creating smart cities is keeping in mind efficiency and productivity of the system. Cities comprise numerous networks of people, jobs, technologies, infrastructure, energy and space [29]. In a smart city, all those networks are interconnected, providing information and supporting each other [30]. As each city is unique, its transition into a smart city will also be unique. For example, Mumbai's and Copenhagen's transformations into smart cities cannot be the same, as they have different options and goals for the transition. A city's development into a smart city typically takes place through several phases. 
In order for a city to turn into a smart city, it has to function well in six areas [31]: - Smart economy - assumes high productivity, entrepreneurship and possibility of transforming into the required economy.

- Smart mobility - comprises powerful information-communication infrastructure and sustainable transportation system [32].

- Smart environment - management of sustainable energy sources, prevention of pollution and environmental protection.

- Smart people - diversity, creativity and public participation.

- Smart life - entails cultural institutions, quality of life, health and security

- Smart government - places importance on political strategies and perspectives, transparency and inclusion of society in decision-making process.

Sustainability has nowadays become a key goal and it requires drastic changes in order for a city as a tourist destination to be pleasant for all its residents, but also its visitors and the generations to come. Sustainability cannot be achieved easily, it is difficult to change habits in society, and it takes time for society to adapt to new circumstances in multiple segments, as can be seen in Figure 2.

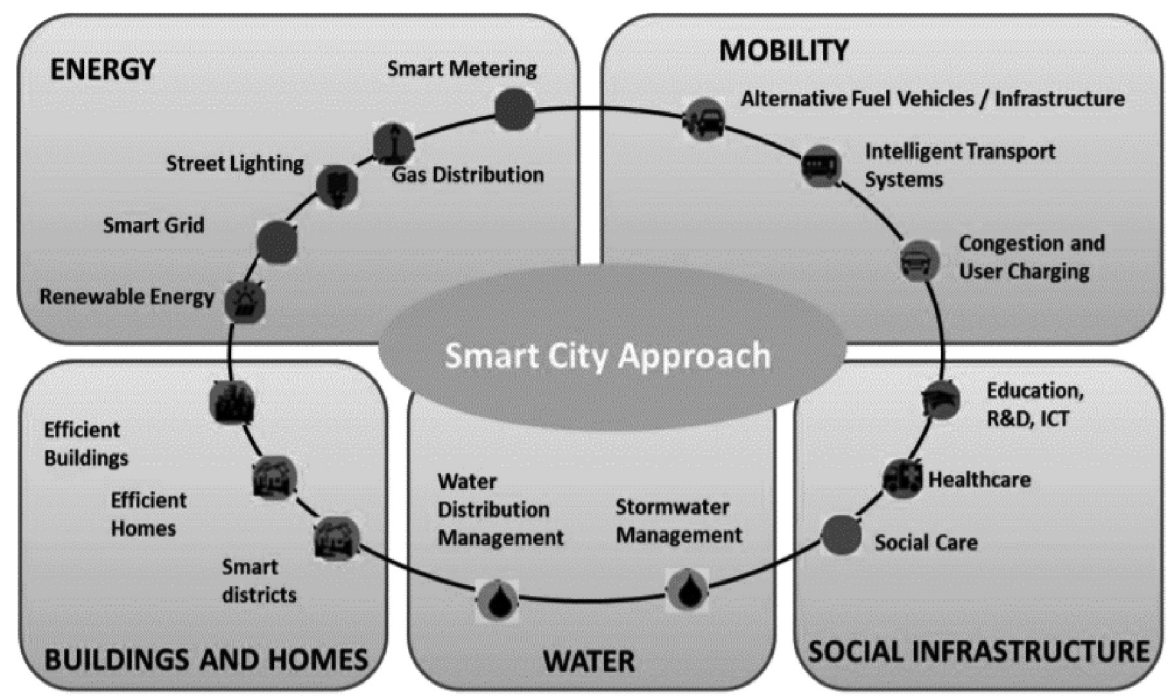

Figure 2 - Description of smart city characteristics and factors [31]

A characteristic of smart cities is that they use physical infrastructure (roads, environment and other physical assets) to efficiently support strong and healthy economic, social and cultural development, they efficiently collaborate with the local population and local government in decision making for process innovation, and utilize the creative industry well $[33,34]$. This is done with the support of high levels of knowledge and social networks to achieve goals in a low-crime environment. Smart 
cities enable online services in various sectors: local economy and development, environmental protection, energy, traffic, security, education, health, trade, residence and management, as well as in various neighbourhoods (markets, ports, airports, industrial zones). All domains of a smart city rely on several knowledge processes that are always present regardless of sector or neighbourhood. The interest for smart cities is motivated by great challenges, including climate change, the restructuring of the economy, transition to online sales and entertainment, population aging, pressure on public funds, etc. The European Union has dedicated constant effort to create a strategy for the development of its region into smart cities and has presented an initiative called „European Innovation Partnership on Smart Cities and Communities“[13]. This initiative aims to divide European energy sources by turning to the development of smart cities in order to support the demonstration of energy, transportation and information-communication technologies in urban areas. Most European capitals are smart cities, along with other smaller or bigger cities worldwide. The pioneers of implementing digital technologies include Luxembourg, Aarhus, Salzburg, Turku, Lienz, Ljubljana, Graz, Eindhoven, Gent, Cardiff, Cork, Aberdeen, Brugge, Maribor, Santiago de Compostela, Verona and many others. Those cities have a sustainable development plan and an initiative to free themselves from fossil fuel consumption, thus reducing $\mathrm{CO} 2$ emissions. Additionally, industries in those cities are turning towards alternative sources of energy and recycling in order to reduce the negative effect of waste generated by the city's population [35]. What smart cities and smart destinations have in common is shown in Figure 1. Since many cities want to become smart the cities, the authors of this paper were interested in attitudes regarding smart cities held by residents living in selected tourist destinations in the Republic of Croatia.

\section{Research design}

\subsection{Research aim}

According to Škrlec [36], Croatia is a relatively conservative society when it comes to adopting new technological ideas and lags behind European urban areas. According to research conducted by the Faculty of Transport and Traffic Sciences in Zagreb [37], however, most studied Croatian cities participate in particular projects on the subject of smart cities, e-management, smart city or similarly named projects, and have stated that they plan to spend some funds to implement the smart city concept (51.7\%). Among the studied Croatian cities, $32 \%$ have started implementing the smart city concept, while $64 \%$ plan to start. According to Paliaga and Oliva [38], particular cities in Croatia have gotten involved in the process of implementing specific components of smart cities. Taking this into consideration, the aim of this paper is to detect gaps in research dealing with citizen attitudes on tourist destinations as smart cities. 


\subsection{Research approach}

The research was conducted in the Kvarner tourist destination in the Republic of Croatia in December 2019, by exploring the attitudes of citizens within the scope of narrow tourist destinations including Lovran ( $\mathrm{N}=45)$, Opatija $(\mathrm{N}=39)$ and Rijeka $(\mathrm{N}=16)$. A structured questionnaire with multiple-choice questions was used, and the examiner circled the answers given. This paper provides an overview of selected relevant attitudes and the results are shown as a graph. The research encompassed a total of 100 randomly selected citizens, and the only conditions were that they were of full age and living in the studied area for over 5 years. They were approached on the most frequented points of the city. Demographic data shows that the research included $45 \%$ men and $55 \%$ women by gender. By age, $38 \%$ of the participants were between 18 and 40 years old, $50 \%$ between 41 and 64 , and $12 \% 65$ years and above. By education, $61 \%$ of the polled people are highly educated (college or higher), $32 \%$ are high school educated, and $17 \%$ have lower levels of education.

\subsection{Research findings}

This research focuses on public perception regarding the smart city concept namely; familiarity with the concept, relation of the concept and tourism development of destination and responsibility of implementing the concept.

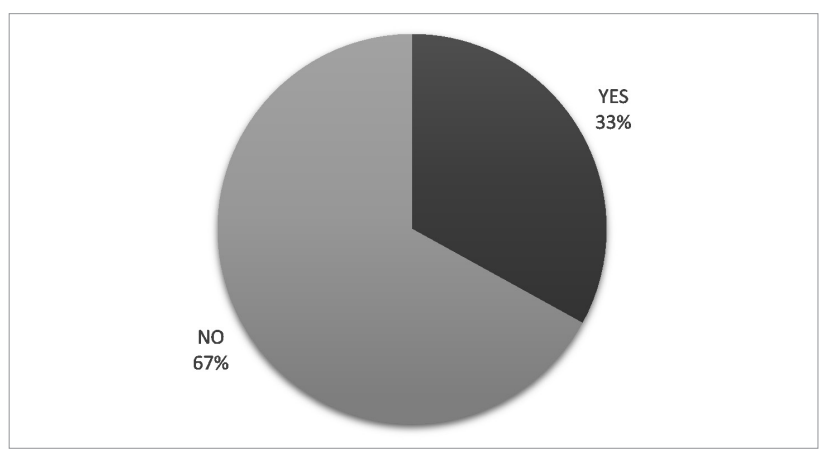

Figure 3 - Familiar with the smart city concept

Source: authors'research

The results show that $67 \%$ of the citizens living in tourist destinations are not familiar with the smart city concept. Such data can be concerning for city management because a lack of interest or lack of knowledge of the local population can be an obstacle for development in the future. It is therefore recommended to better inform citizens with the option of continuous education programmes. 


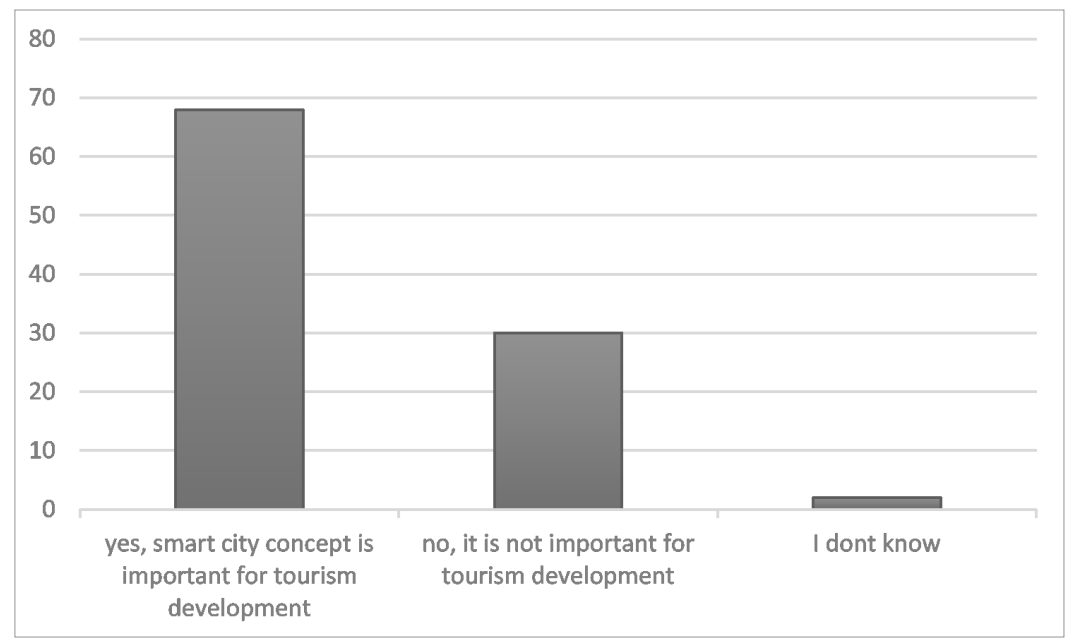

Figure 4 - Link between the smart city concept with the tourism development of a destination

Source: authors'research

When asked whether they thought implementing the smart city concept would positively impacts touristic development, most (68\%) state that it would improve the touristic development of the destination. Even though they are not familiar with the concept itself in great detail, they consider that the development of smart destinations leaves plenty of room for each community undertaking that step to define the shape and functionality of its environment while respecting the community's historical, cultural-artistic and social heritage. The examinees want contemporary development, but they also want to keep the authenticity of their environment. Most agree with the fact that tourists like to visit destinations offering an authentic experience. Introducing the smart city concept takes into consideration diversity, creativity and the development of cultural institutions in combination with a powerful information-communication infrastructure and sustainable transportation. 


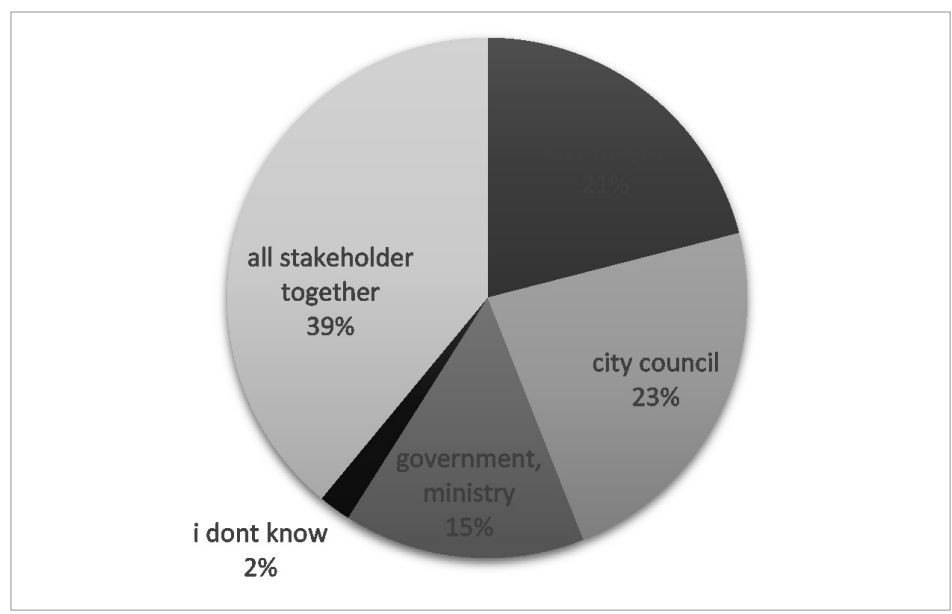

Figure 5 - Responsibility for implementing the smart city concept Source: authors' research

When asked who they perceive to be the most responsible for implementing the smart city concept, most participants (39\%) consider that all stakeholders are responsible, $23 \%$ state the city council, and $21 \%$ stated the mayor is responsible for implementing the smart city concept. Additionally, 15\% stated the Government and ministries are responsible, while 2\% said that they don't know. These results point towards the need to continuously connect all stakeholders in the community with the aim of informing and educating the public on the projects being implemented, for the purpose of achieving a higher quality of life for both the citizens and tourists.

\section{Discussion and conclusion}

Making tourist destinations smarter and more connected does not only entail overcoming the challenges faced by the destinations. It means recognizing that many challenges are focused on creating sustainable cities. Cities symbolize and centralize many aspects that will make the planet smarter: smarter education, smarter public security, smarter traffic and smarter management all for the purpose of a better quality of life.

The smart city concept is based on constant improvement through technological solutions in the process of sustainable development, which at its core, has to involve a smart, efficient system [39]. As tourist destinations continue to develop through their municipal infrastructures, the significance of information-communication technologies and integrated solutions will become widely impactful and irreplaceable. Smart destinations will be measured by the level of integration of ICT infrastructure on all 
levels connecting the energy sector, healthcare, transport, ecology or management. As a tourist destination's sustainability becomes more important than ever, it is no longer a question of whether tourist destinations will do it, but which destinations will do it earlier and better.

Sustainable development is among the most current topics in the world, but it also has to be explored on the micro level and managed using a bottom-up approach. This paper explored the studied destinations on the micro level, and the research results can help key stakeholders in city management with making decisions. The obtained results can be used to inform policy making toward becoming more proactive, smart and sustainable.

The very idea of transforming tourist destinations into smart cities with the aid of technology is relatively new. In some cities, it is still in the process of implementation, while others are not yet even familiar with it. The integration of digital, communication and physical infrastructure is, however, an idea that singularly contains all relevant aspects that make a destination urban. Local development policy makers have to quickly undertake the necessary measures to define solutions for achieving higher quality services for a rising number of people, while taking into consideration both new inhabitants moving to the city and tourists. The answer to these rising issues regarding living in urban areas lies in the system of implementing the smart city concept. Cities are becoming key factors that have to enable the continuous evaluation of all systems that have to be connected in a singular global smart city concept by reducing energy loss, a humane relationship towards the living environment, and primarily through the integration of information-communication technologies. A citizen's daily life must include reliable and safe supply of power and water, an efficient city-wide and intercity transportation system, a developed telecommunications system with broadband connections, efficient local self-government that enables simple non-stop access to information, high quality of knowledge and available intellectual and social capital, as well as a competitive, productive and open local economy.

There is a host of factors disrupting the implementation of the smart city concept. Some of them are technological challenges causing insecurity and risk, technology that is inapplicable in some cities, financial insecurity, city complexity, city operations are multidimensional and entail multiple interested parties interdependent when it comes to decision making. In the private sector, technological companies see the city as a complex multidimensional system. Architects and non-government organizations view the city through the perspective of people, social inclusion and the spatial dimension. The Government, on the other hand, looks at cities from the point of view of economic growth and municipal services supporting politics oriented towards change. Regardless of these different points of view, they all share the same vision - to make cities smarter and more sustainable. The questions that key stakeholders need to answer - why is the smart city concept a good initiative and what value justifies the initiative and innovations? Which actions have to be undertaken? Which projects and initiatives are primarily important? How will the solutions be implemented? Which policies and 
business models should it involve? How will it be financed? How to communicate among each other and towards the citizens? If the city management can answer these questions, it guarantees faster success for the concept's implementation.

Contemporary tourist destinations represent a reflection of the civilization's development, attracting the best human, technological, organizational and natural resources like a strong magnet. Smart destinations have to be developed based on integrated cities, where the awareness of the connections and mutual dependence will be applied to all aspects of human life, as well as the people's relationship with their natural surroundings. The realization of smart destinations represents a significant phase on the road towards creating future integrated cities, which will enable the various complex systems - energy, transport, tourism, environmental protection, management, healthcare, culture and education - to function in harmony. The goal is to unite the citizens and the spirit of the city, and to make it a place where both the citizens and visitors are satisfied.

This paper has many limitations. Research limitations pertain to the analysis of a relatively small number of participants. In addition to a larger number of participants, the research should be conducted on a larger area, involve more destinations as well as more variables.

The recommendation for further research encompasses questions on funding smart solutions, which this paper has not covered. It is recommended to research funding from savings, alternative funding methods and how successfully cities draw funds from European structural funds. Those questions should be asked to key stakeholders in local self-government.

\section{Acknowledegment}

This paper has been fully supported by the University of Rijeka under the project number „uniri-drustv-18-212”.

\section{References}

1. Eremia, M., Toma, L., Sanduleac, M. (2017) The Smart City Concept in the 21st Century. 10th International Conference Interdisciplinarity in Engineering, Procedia Engineering, Vol. 181, pp. 12-19.

2. Carter, D. (2013) Urban regeneration, digital development strategies and the knowledge economy: Manchester case study. Journal of the Knowledge Economy, 4(2), 169-189.

3. United Nations (UN) (2015). Resolution Transforming our world: the 2030 Agenda for Sustainable Development. Available from: http://www.un.org/ga/search/view doc.asp?symbol=A/ RES/70/1\&Lang=E [Accesses 20th March 2020].

4. Angelidou, M. and Psaltoglou, A. (2017) An empirical investigation of social innovation initiatives for sustainable urban development. Sustainable Cities and Society, 33, 113-125.

5. Bibri, S.E. and Krogstie, J. (2017) Smart sustainable cities of the future: an extensive interdisciplinary literature review. Sustainable Cities and Society, 31, 83-212. 
6. Edge, S., Boluk, K., Groulx, M. \& Quick, M. (2020) Exploring diverse lived experiences in the Smart City through Creative Analytic Practice, Cities, 96, 1-11. Available from: https://reader. elsevier.com/reader/sd/pii/S0264275119308418?token=A9E43FD6C4CA3A50FE8BAADE54 42A5F139E70F2DC4C97F5E421482B64C2A3BB4B6B5AECFC72585E2046D675A005C02 7F [Accesses 20th March 2020].

7. Dameri, R. P. (2013) Searching for Smart City definition: a comprehensive proposal. International Jounal of Computers \& Technology, Council for Innovative Research, 11 (5), 2544-2551.

8. Harrison, C., Eckman, B., Hamilton, R., Hartswick, R, Kalagnanam, J., Paraszczak, J. and Williams, P. (2010) Foundations for Smarter Cities. IBM Journal of Research and Development, $54(4), 1-16$.

9. United Nations World Tourism Organization (UNWTO) (2011) Policy and practice for global tourism. Available from: http://pub.unwto.org/WebRoot/Store/Shops/Infoshop/4D93/3C61/ DDD2/4F6C/8E4C/C0A8/0164/5C4F/110330_policy_practice_global_tourism_excerpt.pdf [Accesses 25th March 2020]

10. United Nations (2014) World Urbanization Prospects: The 2014 Revision, Highlights (ST/ESA/ SER.A/ 352), New York. Available from: https://esa.un.org/unpd/wup [Accesses 5th April 2020].

11. Krstinić Nižić, M., Trinajstić, M., Šverko Grdić, Z. (2019) Towards sustainable cities in Croatia, WIT Transactions on Ecology and the Environment, Sustainable City XIII, 13th International Conference on Urban Regeneration and Sustainability, Valencia, Spain, Vol. 238, UK: WIT Press, 443-454.

12. Tan, S. Y. \& Taeihagh, A. (2020) Smart City Governance in Developing Countries: A Systematic Literature Review, Sustainability, 12, 899, 1-12.

13. European Commission (2012) Communication from the Commision: Smart Cities and Communities - European Innovation Partnership, European Commission, Brussels. European Innovation Partnership on Smart Cities and Communities, Available from: https://e3p.jrc. ec.europa.eu/articles/european-innovation-partnership-smart-cities-and-communities [Accesses 15th April 2020].

14. Krstinić Nižić, M., Blažević, B. (2017) Gospodarenje energijom u turizmu, University of Rijeka, Faculty of Tourism and Hospitality Management, Opatija.

15. Strielkowski, W., Veinbender, T., Tvaronavičienè, M. \& Lace, N. (2020) Economic efficiency and energy security of smart cities, Economic Research, 33,1, 788-803, DOI: 10.1080/1331677X.2020.1734854

16. Maurya, S. P., Singh, P.K., Ohri, A., Singh, R. (2020) Identification of indicators for sustainable urban water development planning, Ecological Indicator. 108, 1-9. Available from: http://idr-lib.iitbhu. ac.in:8080/xmlui/bitstream/handle/123456789/595/Identification-of-indicators-for-sustainableurban-water-development-planning2020Ecological-Indicators.pdf? sequence=1\&isAllowed=y [Accessed 15 April 2020].

17. Perić, J., Šverko Grdić, Z. (2017) Klimatske promjene i turizam, University of Rijeka, Faculty of Tourism and Hospitality Management, Opatija.

18. Komninos, N. (2015) The Age of Intelligent Cities; Smart Environments and Innovation-for-All Strategies, Routledge.

19. Kramers, A., Höjer, M., Lövehagen, N. and Wangel, J. (2014) Smart sustainable cities - exploring ICT solutions for reduced energy use in cities. EnvironmentalModelling\&Software, 56, 52-62.

20. Leydesdorff, L. and Deakin, M. (2011) The Triple-Helix Model of Smart Cities: A NeoEvolutionary Perspective, Journal of Urban Technology, 18(2), 53-63.

21. Caragliu, A., de Bo, C., Nijkamp, P. (2009) Smart cities in Europe. $3^{\text {rd }}$ Central European Conference in Regional Science, pp. 45-59.

22. Caragliu, A., Del Bo, C. and Nijkamp, P. (2011) Smart cities in Europe. Journal of Urban Technology, 18 (2), 65-82.

23. McCann, P. \& Ortega-Argiles, R. (2015) Smart specialization, regional growth and applications to european union cohesion policy, Regional Studies, 49 (8), 1291-1302.

24. Boschma, R. (2016) Smart specialisation and regional innovation policy, Welsh Economic Review, (24), 17.

25. European Commission (2016) Smart Cities and Communities. Available from: http://ec.europa. eu/eip/smartcities/ [Accessed 15 April 2020]. 
26. Kollar, M., Bubbico, R.L., Arsalides, N. (2018) Smart cities, Smart Investment in Central, Eastern and South-Eastern Europe, A report by the EIB Economics Department. Available from: https:// www.eib.org/attachments/efs/smart_cities_smart_investments_in_cesee_en.pdf [Accessed 15 April 2020].

27. Jun, M. Y., Kwon, J. H., Jeong, J. E. (2013) The effects of high-density suburban development on commuter mode choices in Seoul, Korea. Cities, 31, 230-238.

28. Akande, A.; Cabral, P.; Gomes, P.; Casteleyn, S. (2019) The Lisbon ranking for smart sustainable cities in Europe. Sustainable Cities and Society, 44, 475-487.

29. Shmelev, S.E.; Shmeleva, I.A. (2019) Multidimensional sustainability benchmarking for smart megacities. Cities, 91, 134-163.

30. Martin, C.; Evans, J.; Karvonen, A.; Paskaleva, K.; Yang, D.; Linjordet, T. (2019) Smartsustainability: A new urban fix? Sustain. Cities Soc. 45, 640-648.

31. European Investment Bank (EIB), Investing in smart cities, Available from: https://www.eib.org/ attachments/smart cities factsheet en.pdf [Accessed 15 April 2020].

32. Vilke, S. \& Ostović, I. (2019) Sustainability and New Technologies in Urban Transport and Mobility, Pomorski zbornik, 56 (1), 73-88. Available from: https://hrcak.srce.hr/index. php?show=clanak\&id clanak jezik=326911 [Accessed 20 April 2020].

33. Krstinić Nižić, M., Rudan, E. \& Trinajstić, M. (2019). The role of creative cities in regional development, Business Excellence, 13 (1), 35-55.

34. Krstinić Nižić, M. \& Fugošić, N. (2019) Integrated sustainable development on a local level - the island of Krk as an example, Pomorski zbornik. 56 (1), 89-108. Available from: https://hrcak.srce. $\mathrm{hr} / 224137$ [Accessed 20 April 2020].

35. Mingaleva, Z., Vukovic, N., Volkova, I., Salimova, T. (2020) Waste Management in Green and Smart Cities: A Case Study of Russia. Sustainability, 12 (1), 94, 1-16.

36. Škrlec, D. (2017). Pametni gradovi - budućnost ili stvarnost?. Available from: https://www. davor-skrlec.eu/pametni-gradovi-buducnost-ili-stvarnost/ [Accessed 10 April 2020].

37. Fakultet za prometne znanosti, Zagreb (2017) U Hrvatskoj 40 gradova primjenjuje koncept pametnog grada. Available from: https://aktualno.hr/u-hrvatskoj-40-gradova-primjenjujekoncept-pametnoggrada/ [Accessed 15 April 2020].

38. Paliaga, M., Oliva, E. (2018) Trendovi u primjeni koncepta pametnih gradova, Ekonomska misao i praksa, (2), 565-583.

39. Chourabi, H., Nam, T, Walker, S., Gil-Garcia, J. R., Mellouli, S., Nahon, K., Pardo, T, A. and Scholl, H. J. (2012) Understanding smart cities: An integrative framework. Proceedings of 45th Hawaii International Conference on System Science (HICSS), IEEE, pp. 2289-2297. 
